\title{
Response surface methodology for optimizing fermentation conditions of goat yogurt with Bifidobacterium bifidum and Lactobacillus casei
}

\author{
He Chen, Chunju Bao, Guowei Shu*, Changfeng Wang \\ School of Food and Biological Engineering, Shaanxi University of Science \& Technology, Xi'an, China
}

\section{A B S T R A C T}

\begin{abstract}
Probiotic bacteria have been widely applied in food industry, especially in dairy product and functional food. The objective of present work was to optimize fermentation conditions of goat milk with B. bifidum and L. casei. A Box-Behnken design was employed to investigate the effects of fermentation temperature, strain ratio and inoculum size on viable counts of B. bifidum and L. casei, total bacteria counts and sensory value during fermentation on the basis of $S$. thermophilus and $L$. bulgaricus as starter cultures. The results showed that the quality of goat yogurt was best at the conditions of $41^{\circ} \mathrm{C}$, strain ratio, $2: 1: 1$; inoculum size, $6 \%$. Under the optimum conditions, the viable counts of $B$. bifidum, $L$. casei, total bacteria and sensory value reached at $(1.31 \pm 0.07) \times 10^{8} \mathrm{cfu} / \mathrm{mL},(2.67 \pm 0.09) \times 10^{7} \mathrm{cfu} / \mathrm{mL}$ $(1.62 \pm 0.06) \times 10^{9} \mathrm{cfu} / \mathrm{mL}$ and $7.52 \pm 0.11$, respectively. There was no significant difference between the predicted value and the verification results $(p<0.05)$. The optimum fermentation conditions shown positive effects on the response value which can be propose for goat milk fermented productions.
\end{abstract}

Keywords: Box-Behnken design; Fermentation conditions; Goat milk; Probiotics

\section{INTRODUCTION}

Goat milk and its products of cheese, yogurt and powder have three aspects' significance in human nutrition: Feed starving and malnourished person; treat people afflicted with cow milk allergies and gastro-intestinal disorders; and fill the consumers' gastronomic needs (Haenlein, 2004; Betoret et al., 2003). However, the research data of milk mainly concentrate in cow milk at home and abroad, due to some physical and chemical properties differences between goat milk and cow milk (Wang et al., 2002). In fact, there is no significant difference in nutritional value between goat milk and cow milk. Some proteins in cow milk such as $\alpha$-lactalbumin and $\beta$ - lactalbumin is now recognized as allergens, whereas goat milk can relieve most allergy caused by proteins, this is because of the amount and structural differences in whey proteins, and it is more easily digestible and absorbed than cow milk for its' small fat globules (1.5mm) (Raynal-Ljutovac, et al., 2005; Sheehan, et al., 2009; Albenzio and Santillo, 2011), and long-term drinking goat's milk does not cause weight gain. Furthermore, goat milk is rich in protein, fat, vitamins (A and complex B) and minerals (calcium content) (Keogh and O'Kennedy, 1998; Silanokove, et al., 2010; Haenlein and Anke, 2011), and it is recognized as the world's dairy products which is closest to human milk (Saarela et al., 2002; Rafter, 2003).

Goat milk production has gradually risen for its high nutritional value and its nutritional benefits can be improved by adding probiotics such as B. lactis and L. acidophilus. $S$. thermophilus and L. bulgaricus are the common bacteria that use for fermentation milk in the market, but these two kind of bacteria can not tolerant of hydrochloric acid in gastric juice and bile and not colonize the intestinal, thus, the beneficial effect of it was limited (Gao, 2004). The bacteria L. bulgaricus belongs to one kinds of the lactic acid bacteria and has been used as a probiotics culture (Van de Guchtel et al., 2006), and it is very important for the food industry to combine with $S$. thermophilus. Probiotics bring health benefits to the host by polishing up its intestinal microbial balance when intake in appropriate amounts (Kanmani et al., 2013; Scholz-Ahrensa et al., 2016). The increasing use of probiotics goat milk is mainly driven by improving consumer health consciousness (Ming et al.,
*Corresponding author:
Guowei Shu, School of Food and Biological Engineering, Shaanxi University of Science \& Technology, Xi'an 710021, China.
E-mail: shuguowei@gmail.com

Received: 24 September 2015;
Accepted: 02 June 2016;

Published Online: 02 June 2016 
2009), and with the improvement of awareness of people for health care, adding probiotics in yogurt production will be a good application (Tharmaraj and Shah, 2000).

In recent years, there is a trend in the making products of probiotics with the combinations of two or more probiotics strains and it was used to increase the health value of each strain (Collado et al., 2007). With goat milk as raw material, choosing five kinds of lactic acid bacteria to develop a function goat milk containing $\gamma$ - aminobutyric acid (GABA) and angiotensin-converting enzyme (ACE) inhibitory peptides, which could improve the function of the human body, reduce blood pressure, relieve the heart and brain vascular disease and nervous disease (Minervini et al., 2009). Besides, probiotics can treat diseases like lactose intolerance, food allergy, acute gastroenteritis, crohn's disease, microbial community structure changes, cancer preventive, et al. (Marco et al., 2006; Million and Raoult., 2012; Unno et al., 2015; Desrouillères et al., 2015).

The influence of variation of parameters such as fermentation temperature, inoculum size and initial cocci/rods ratio on the fermentation process of yogurt was studied by using response surface methodology, and the method was useful for a better fermentation process which considering optimal combinations of the factors (Torriani et al., 1996). Fermentation temperature could affect the growth of yogurt bacteria and flavor of yogurt (Radke-Mitchell and Sandine, 1986; Guler-Akın and Akın, 2007). Inoculum size could affect a normal acidification process (Burgain, et al. 2013) and to ensure final viable counts of bacteria to be a desired level at the end of fermentation (Chen, et al., 2015).

In our previous work, the single factor and orthogonal experiment have been conducted to optimize the fermentation conditions of goat milk fermented by $S$. thermophilus and L. bulgaricus (Chen et al., 2010). Effect of fermentation temperature, strain ratio and inoculum size on goat yogurt fermented by Bifidobacterium bifidum and Lactobacillus casei was also studied by the single factor experiments (Shu et al., 2015a,b). The aim of the present study is to optimize fermentation conditions of goat yogurt containing B. bifidum and L. casei (BC-goat yogurt) through response surface methodology, and improve the viable counts in fermentation broth and then provide a theoretical basis for quality control in the goat milk productions.

\section{MATERIALS AND METHODS}

\section{Strain and culture preparation}

Starter bacteria of L. casei (LC), B. bifidum (BB), S. thermopbilus and $L$. bulgaricus were obtained from the School of Food and
Biological Engineering, Shaanxi University of Science and Technology. MRS (for LC, BB and L. bulgaricus) and M17 (for S. thermophilus) and TJA were purchased from Qingdao Haibo Biological Technology Co., Ltd. Skimmed milk was purchased from a local retail store. All reagents used in the experiment were of analytical grade dissolved with distilled water and formulated into various concentrations.

L. bulgaricus and $S$. thermophilus freeze-dried power were inoculated with MRS and M17 medium, and then cultivated at $37^{\circ} \mathrm{C}$ for $24 \mathrm{~h}$. Repeated the experiments several times until bacteria viability is stable judged by microscopic, and then 3-5\% bacteria which had been fully activated was inoculated with sterile skim goat milk in anaerobic tube, mixed and cultivated at $42^{\circ} \mathrm{C}$ (for L. bulgaricus and S. thermophilus) and $37^{\circ} \mathrm{C}$ (for L. casei and B. bifidum), respectively. After that, 3\% 5\% skimmed milk was inoculated with sterile whole goat milk in the flask after solidification, mixed and cultivated in the incubators, which can be used for the production of goat milk.

Viable bacterial and probiotics counts determination Top agar method and plate coating method were used to determine viable bacterial counts, among them, the viable counts were determined by modified Tomato Juice Medium(TJA), MRS agar containing $0.06 \%$ bile salt or $0.1 \% \mathrm{LiCl}$ was used to determine viable bacterial counts of $L$. acidophilus and $L$. case $i$ in fermentation goat milk (Shu et al., 2011). Selective counting was used to determine the number of probiotics, and finally get viable bacteria and probiotics counts in goat yogurt products can reached more than $10^{9} \mathrm{cfu} / \mathrm{mL}, 10^{6} \mathrm{cfu} / \mathrm{mL}$, respectively.

\section{Sensory evaluation}

The sensory evaluation of the product was carried out with an internal panel consisting of 5 assessors (aged 28-45 years). Subject persons were selected for their sensory ability and trained for descriptive analysis according to the standard flavor profile guidelines set by ISO 6564:1985. The sensory properties of the product were surface appearance, taste, smell, structural state, whey precipitation and other sensory properties, and scoring standard was shown in Table 1.

\section{Response surface optimization of fermentation conditions}

Based on the determined key factors, a 3-variable and 3-level design method was selected to build response surface models (Box and Behnken, 1960). The coded variables and their respective level are given in Table 2.The design was employed to find the optimal fermentation conditions of goat milk by fitting a polynomial model through response surface methodology (RSM). This methodology is applied to determine the maximum response value and evaluation 
Table 1: The sense evaluation standard of goat yogurt

\begin{tabular}{|c|c|c|c|c|}
\hline Project & Bad & Common & Good & Very good \\
\hline $\begin{array}{l}\text { Color } \\
\text { (1 point) }\end{array}$ & $\begin{array}{l}\text { Gray or atypical } \\
\text { color }(0 \sim 0.25)\end{array}$ & $\begin{array}{l}\text { Color is uneven, } \\
\text { Pale yellow/light gray }(0.25 \sim 0.50)\end{array}$ & $\begin{array}{l}\text { Color is uniform basically, } \\
\text { creamy/milky }(0.50 \sim 0.75)\end{array}$ & $\begin{array}{l}\text { Color is uniform, } \\
\text { milky }(0.75 \sim 1.00)\end{array}$ \\
\hline $\begin{array}{l}\text { Smell } \\
\text { (3points) }\end{array}$ & $\begin{array}{l}\text { Lack of flavor } \\
(0 \sim 0.75)\end{array}$ & $\begin{array}{l}\text { Flavor is slightly, } \\
\text { slight goaty flavor }(0.75 \sim 1.50)\end{array}$ & $\begin{array}{l}\text { Pure yogurt flavor, slight } \\
\text { goaty flavor (1.50 2.25) }\end{array}$ & $\begin{array}{l}\text { Fragrance/pure yogurt flavor, } \\
\text { no criticism }(2.25 \sim 3.00)\end{array}$ \\
\hline $\begin{array}{l}\text { Taste } \\
\text { (3 points) }\end{array}$ & $\begin{array}{l}\text { Corruption/moldy } \\
(0 \sim 0.75)\end{array}$ & $\begin{array}{l}\text { Sour and sweet taste are too } \\
\text { strong or weak }(0.75 \sim 1.50)\end{array}$ & $\begin{array}{l}\text { Sweet and sour } \\
\text { moderate, little } \\
\text { astringency (1.50 2.25) }\end{array}$ & $\begin{array}{l}\text { Sweet and sour moderate, } \\
\text { no criticism }(2.25 \sim 3.00)\end{array}$ \\
\hline $\begin{array}{l}\text { Structural } \\
\text { state } \\
\text { (3 points) }\end{array}$ & $\begin{array}{l}\text { Adverse curd, } \\
\text { bubbles, whey } \\
\text { precipitation } \\
\text { serious }(0 \sim 0.75)\end{array}$ & $\begin{array}{l}\text { Curd uneven, } \\
\text { not strong, } \\
\text { whey separation } \\
(0.75 \sim 1.50)\end{array}$ & $\begin{array}{l}\text { Curd is good, state is } \\
\text { uniform and fine, little whey } \\
\text { precipitation } \\
(1.50 \sim 2.25)\end{array}$ & $\begin{array}{l}\text { No bubbles, no whey } \\
\text { precipitation } \\
(2.25 \sim 3.00)\end{array}$ \\
\hline
\end{tabular}

of the main effects, interaction effects, and quadratic effects.

\section{Validation of the model}

To optimize fermentation conditions of goat milk by using response surface method, and carry out further fermentation experiments which was based on optimized parameters, the effective of model was verified by making comparison of model predictive value and experimental values.

\section{Statistical analysis}

Box-Behnken experiments were carried out by DesignExpert 8.0.6 statistical software and regression analysis of the experimental data to estimate the response of the independent variables. The quality of the fit of the secondorder model equations was expressed by the coefficient of determination $\left(\mathrm{R}^{2}\right)$ and $p<0.05$ was considered statistically significant for all analysis.

\section{RESULTS AND DISCUSSION}

\section{Experimental design and results of Box-Behnken}

In order to optimize fermentation conditions of skimmed goat milk fermentation temperature (A), the strain ratio (B), and inoculum size (C), response surface methodology (RSM) which has been demonstrated to allow evaluation of the effects of multiple parameters on response variables (Pinho et al., 2011)was used. Among them, the strain ratio is about (BB: LC:(LB: ST)), L.bulgaricus and S.thermophilus are used as basic culture medium. The corresponding Box-Behnken design and the results are listed in Table 3. The viable counts of B.bifidum and L.casei were represented by $\mathrm{Y}_{1}\left(\times 10^{6} \mathrm{cfu} / \mathrm{mL}\right), \mathrm{Y}_{2}\left(\times 10^{7} \mathrm{cfu} / \mathrm{mL}\right)$, respectively. The number of total bacteria was represented by $\mathrm{Y}_{3}\left(\times 10^{9} \mathrm{cfu} / \mathrm{mL}\right)$ and sensory value was represented by $\mathrm{Y}_{4}$.

\section{Regression analysis}

A quadratic model could predict the response at any point, even the data not included in the design. Multiple regression equation correlating the response function with the
Table 2: Factors and levels for optimizing fermentation conditions of BC-goat yogurt

\begin{tabular}{lccc}
\hline Independent variables & \multicolumn{3}{c}{ Level } \\
\cline { 2 - 4 } & $-\mathbf{1}$ & $\mathbf{0}$ & $\mathbf{1}$ \\
\hline A fermentation temperature $\left({ }^{\circ} \mathrm{C}\right)$ & 37 & 39 & 41 \\
B strain ratio & $1: 1: 1$ & $2: 1: 1$ & $3: 1: 1$ \\
C inoculum size (\%) & 6 & 7 & 8 \\
\hline
\end{tabular}

Strain ratio refers to BB: LC:(LB: ST)

Table 3: The experimental design and results of Box-Behnken design for BC-goat yogurt

\begin{tabular}{cccccccc}
\hline Run & A & B & $\mathbf{C}$ & $\begin{array}{c}\text { BB }\left(\mathbf{Y}_{1}\right) \\
\left(\times 10^{6} \mathrm{cfu} / \mathrm{mL}\right)\end{array}$ & $\begin{array}{c}\mathrm{LC}\left(\mathrm{Y}_{2}\right) \\
\left(\times 10^{7} \mathrm{cfu} / \mathrm{mL}\right)\end{array}$ & $\begin{array}{c}\text { Total } \\
\text { Bacteria }\left(\mathrm{Y}_{3}\right) \\
\left(\times 10^{9} \mathrm{cfu} / \mathrm{mL}\right)\end{array}$ & $\begin{array}{c}\text { Sensory } \\
\text { value } \\
\left(\mathrm{Y}_{4}\right)\end{array}$ \\
\hline 1 & -1 & -1 & 0 & 3.2 & 1.8 & 1.70 & 6.69 \\
2 & 1 & -1 & 0 & 9.2 & 2.9 & 1.53 & 6.88 \\
3 & -1 & 1 & 0 & 4.9 & 1.7 & 1.72 & 6.27 \\
4 & 1 & 1 & 0 & 16.6 & 1.1 & 1.73 & 6.91 \\
5 & -1 & 0 & -1 & 2.5 & 3.5 & 1.71 & 6.39 \\
6 & 1 & 0 & -1 & 12.9 & 2.8 & 1.68 & 7.53 \\
7 & -1 & 0 & 1 & 7.1 & 1.6 & 1.64 & 7.07 \\
8 & 1 & 0 & 1 & 16.2 & 2.6 & 1.66 & 7.02 \\
9 & 0 & -1 & -1 & 5.5 & 3.3 & 1.65 & 7.14 \\
10 & 0 & 1 & -1 & 3.1 & 2.1 & 1.67 & 7.32 \\
11 & 0 & -1 & 1 & 5.8 & 3.2 & 1.43 & 7.15 \\
12 & 0 & 1 & 1 & 6.0 & 3.1 & 1.49 & 6.84 \\
13 & 0 & 0 & 0 & 6.8 & 4.5 & 1.42 & 7.22 \\
14 & 0 & 0 & 0 & 5.3 & 4.0 & 1.45 & 7.03 \\
15 & 0 & 0 & 0 & 7.8 & 3.9 & 1.36 & 7.08 \\
\hline
\end{tabular}

independent variables could be established using the data provided by Box-Behnken Design. And the multivariate quadratic regression model which was used to determine the individual effects and mutual interaction effects of candidate variables can be got as follows:

$\mathrm{Y}_{1}=1131.17-6053 \mathrm{~A}-26.01 \mathrm{~B}+8.76 \mathrm{C}+0.71 \mathrm{AB}-$ $0.16 \mathrm{AC}+0.65 \mathrm{BC}+0.80 \mathrm{~A}^{2}-1.37 \mathrm{~B}^{2}-0.17 \mathrm{C}^{2}$

$\mathrm{Y}_{2}=-452.23+23.93 \mathrm{~A}+9.88 \mathrm{~B}-5.78 \mathrm{C}-$ $0.21 \mathrm{AB}+0.21 \mathrm{AC}+0.28 \mathrm{BC}-0.32 \mathrm{~A}^{2}-0.98 \mathrm{~B}^{2}-0.23 \mathrm{C}^{2}$

$\mathrm{Y}_{3}=80.63-3.73 \mathrm{~A}-1.21 \mathrm{~B}-1.39 \mathrm{C}+0.02 \mathrm{AB}+0.006 \mathrm{AC}+0.063$ $\mathrm{BC}+0.047 \mathrm{~A}^{2}+0.07 \mathrm{~B}^{2}+0.08 \mathrm{C}^{2}$ 
$\mathrm{Y}_{4}=-129.81+6.28 \mathrm{~A}-0.82 \mathrm{~B}+3.79 \mathrm{C}+0.06 \mathrm{AB}-0.15 \mathrm{AC}-$ $0.12 B C-0.07 A^{2}-0.16 B^{2}+0.16 C^{2}$

Where $A, B$ and $C$ are independent variables, $Y_{1}, Y_{2}, Y_{3}$ and $\mathrm{Y}_{4}$ represents the corresponding expected values including the viable counts of B. bifidum, L. casei, total bacteria and sensory value, respectively.

\section{Variance analysis}

Analysis of variance (ANOVA) is a method to study the controlled variables that are significant to the observed variables and evaluate the adequacy of the fitted model. The F-test was used to determine the effect of each variable, and the smaller of the $\mathrm{p}$ value, the more significant was the effect of the variables; the R-squared value was used to describe the variability in the actual response values that could be explained by the experimental factors and their interactions (Siti Aminah et al., 2006). Analysis of variance for the developed polynomial model is shown in Table 4. The next step was to obtain the optimum value for each factor to get the maximum response. The plots' curvatures suggest the interaction between the factors. Threedimensional graphs that could evaluate the interactive effects of the two factors on the response were in Fig. 1.

As is shown in Table 4, the probability value for B. bifidum $(p=0.0284<0.05)$ demonstrated a high significance for the regression model, and the probability for the lack of fit $(p=0.2053>0.05)$ is insignificant which indicated that the regression analysis is effective. The model equation as expressed in Eq. (1) is confirmed to be a suitable model to describe the response of the value of the survival rate. Furthermore, the adjusted $\mathrm{R}$-squared $\left(\mathrm{R}_{\text {adj }}{ }\right)$ can measure the amount of variation around the mean explained by the model adjusted for the number of terms and Predicted $\mathrm{R}$-square $\left(\mathrm{R}_{\text {pred }}^{2}\right)$ can measure of the amount of variation in new data explained by the model, and the $\mathrm{R}_{\text {pred }}^{2}$ and the $\mathrm{R}_{\text {adj }}^{2}$ should be within 0.20 of each other, otherwise there may be a problem with either the data or the model (Ara et al., 2013). The $\mathrm{R}_{\text {adj }}^{2}$ values (0.7729) for the above model $\left(\mathrm{R}_{\text {adj }}^{2}-\mathrm{R}_{\text {pred }}^{2}=0.1393<0.2\right)$ indicated that the model was highly significant. The coefficient of determination $\left(\mathrm{R}^{2=} 0.9189\right)$ was calculated, which indicated that more than $91.89 \%$ of variability in the response could be explained by the second-order polynomial predicted equation given already. Parameter of A was the main factor affecting the viable counts of B. bifidum which was depicted in Fig. 1a, besides, the quadratic $A^{2}$ is also significant terms in this model (Table 4). The viable counts of B. bifidum increased were shown with fermentation temperature increasing in Fig. $1 \mathrm{a} . \mathrm{A} \times \mathrm{B}, \mathrm{A} \times \mathrm{C}$ and $\mathrm{B} \times \mathrm{C}$ all showed a weak mutual interaction between them on the effect of viable counts for B. bifidum (Table 4), which indicates that the effect of one agent concentration on viable counts was dependent on the level of another one.

The probability value for $L$. casei $(p=0.0047<0.05)$ is significance and the probability for the lack of fit $(p=0.22158>0.05)$ is insignificant which indicated that the analysis is effective for the regression model. The model equation in Eq. (2) is confirmed to be a suitable model. The coefficient of determination $\mathrm{R}^{2}$ was 0.8985 , indicating that $89.85 \%$ of variability could be explained by the model. The high F-value of $\mathrm{A}^{2}$ (21.86) and $\mathrm{B}^{2}$ (12.81) implied that it was not a simple linear correlation for the viable counts of $L$. casei, while $\mathrm{C}^{2}$ was not significant. Furthermore, all factors examined including their quadratic and mutual interaction terms, significantly affected the viable counts for L. casei except $\mathrm{A}^{2}$ and $\mathrm{B}^{2}$, the effect of others all were not significant, as shown in Table 4. With their quadratic and interaction terms, all factors except $\mathrm{A}^{2}$ and $\mathrm{B}^{2}$ don't have a significant effect the sensory value. The interaction of strain ratio and inoculum size was depicted in Fig. 1b. As it shown that the two-dimensional contour plots seemed to be

Table 4: Analysis of variance for the developed polynomial model

\begin{tabular}{|c|c|c|c|c|c|c|c|c|c|c|c|c|c|}
\hline \multirow[t]{2}{*}{ source } & \multicolumn{4}{|c|}{ BB } & \multicolumn{3}{|c|}{ LC } & \multicolumn{3}{|c|}{ Total Bacteria } & \multicolumn{3}{|c|}{ Sensory Value } \\
\hline & DF $^{a}$ & MS $^{b}$ & $\mathrm{~F}^{\mathrm{c}}$ & $\mathbf{P r}^{\mathrm{d}}$ & MS $^{b}$ & $F^{c}$ & $\mathbf{P r}^{\mathrm{d}}$ & MS $^{b}$ & $F^{c}$ & $\mathbf{P r}^{\mathrm{d}}$ & MS $^{b}$ & $F^{c}$ & $\mathrm{Pr}^{\mathrm{d}}$ \\
\hline Model & 9 & 28.06 & $6.29^{*}$ & 0.0284 & 1.36 & $4.92^{*}$ & 0.0471 & 0.023 & $5.37^{*}$ & 0.0394 & 0.16 & 9.1 & 0.0128 \\
\hline A & 1 & 172.98 & $38.79^{* *}$ & 0.0016 & 0.08 & 0.29 & 0.6136 & 0.0036 & 0.84 & 0.4012 & 0.46 & 26.33 & 0.0037 \\
\hline B & 1 & 5.95 & 1.33 & 0.3002 & 1.28 & 4.63 & 0.084 & 0.011 & 2.62 & 0.1665 & 0.034 & 1.93 & 0.2233 \\
\hline C & 1 & 15.4 & 3.45 & 0.1222 & 0.18 & 0.65 & 0.4563 & 0.03 & $6.99^{*}$ & 0.0458 & 0.011 & 0.64 & 0.4591 \\
\hline$A \times B$ & 1 & 8.12 & 1.82 & 0.235 & 0.72 & 2.61 & 0.1668 & 0.0081 & 1.89 & 0.228 & 0.051 & 2.89 & 0.1497 \\
\hline$A \times C$ & 1 & 0.42 & 0.095 & 0.7706 & 0.72 & 2.61 & 0.1668 & 0.0006 & 0.15 & 0.7185 & 0.35 & 20.23 & 0.0064 \\
\hline $\mathrm{B} \times \mathrm{C}$ & 1 & 1.69 & 0.38 & 0.5651 & 0.3 & 1.09 & 0.3434 & 0.0004 & 0.093 & 0.7725 & 0.06 & 3.43 & 0.1232 \\
\hline$A^{2}$ & 1 & 38.01 & $8.52^{*}$ & 0.033 & 6.04 & $21.86^{* *}$ & 0.0055 & 0.13 & $29.82^{\star *}$ & 0.0028 & 0.26 & 14.96 & 0.0118 \\
\hline$B^{2}$ & 1 & 6.9 & 1.55 & 0.2688 & 3.54 & $12.81^{*}$ & 0.0159 & 0.02 & 4.68 & 0.0829 & 0.09 & 5.15 & 0.0725 \\
\hline$C^{2}$ & 1 & 0.1 & 0.023 & 0.8854 & 0.19 & 0.7 & 0.4404 & 0.021 & 5 & 0.0756 & 0.093 & 5.32 & 0.0693 \\
\hline Lack of fit & 3 & 6.38 & 4.03 & 0.2053 & 0.39 & 3.79 & 0.2158 & 0.0058 & 2.74 & 0.2785 & 0.023 & 2.45 & \\
\hline errors & 2 & 1.58 & & & 0.1 & & & 0.0021 & & & 0.0097 & & \\
\hline $\mathrm{R}^{2}$ & \multicolumn{4}{|c|}{0.9189} & \multicolumn{3}{|c|}{0.8985} & \multicolumn{3}{|c|}{0.9063} & \multicolumn{3}{|c|}{0.9449} \\
\hline
\end{tabular}

${ }^{* *} p<0.01 ;{ }^{*} p<0.05$; ${ }^{2}$ Degrees of freedom; ${ }^{b}$ Mean square; ${ }^{\circ}$ Test for comparing model variance with residual (error) variance; ${ }^{\mathrm{d}}$ The probability values 


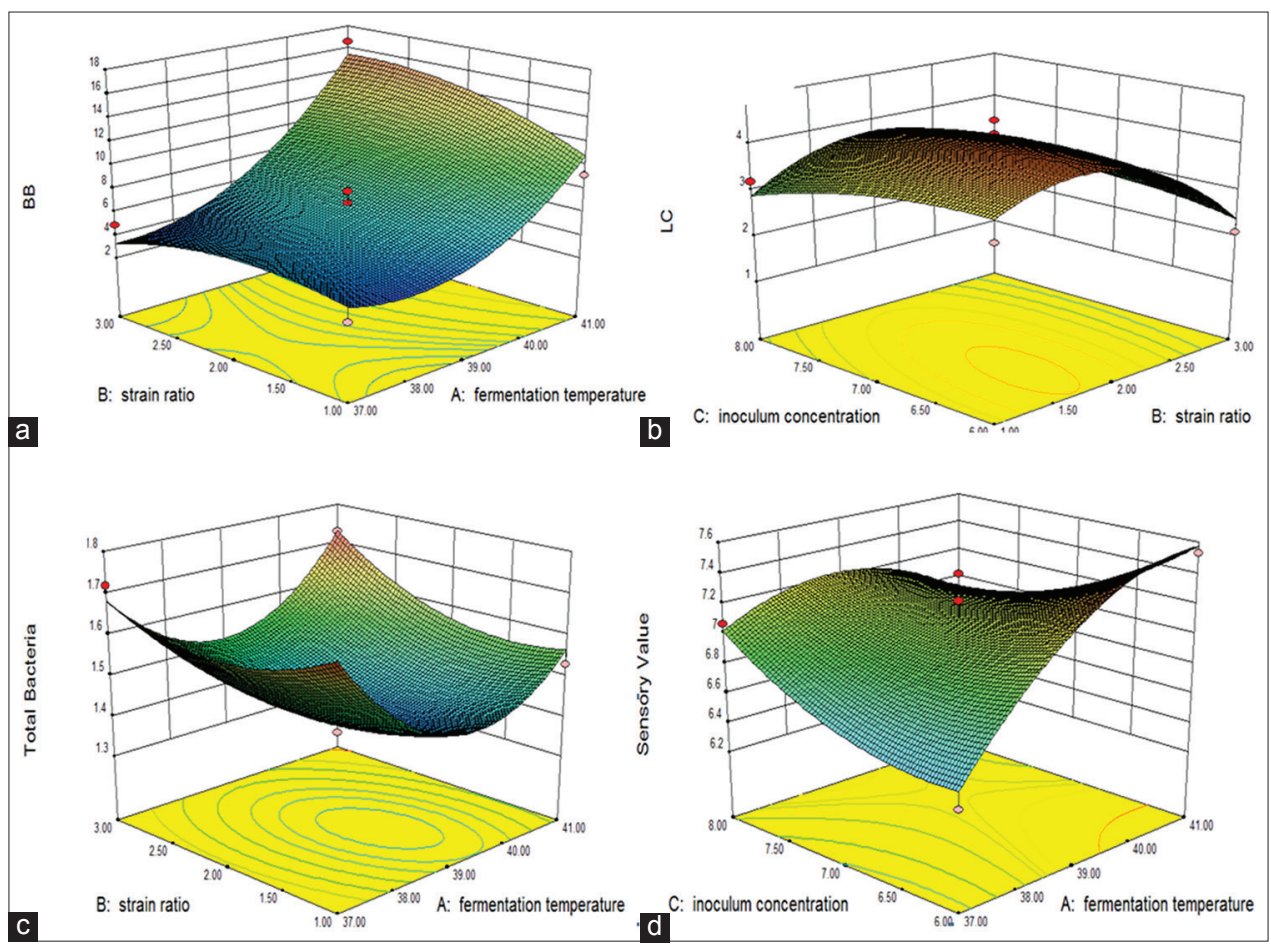

Fig 1. Response using the Box-Behnken design obtained by plotting: (a) fermentation temperature versus strain ratio (inoculum size, $7 \%$ ); (b) strain ratio versus inoculum size $\left(41^{\circ} \mathrm{C}\right)$; (c) fermentation temperature versus strain ratio (inoculum size, $7 \%$ ); and (d) fermentation temperature versus inoculum size (strain ratio, 2: 1: 1).

a circle; this indicates that the mutual interaction of terms $\mathrm{B} \times \mathrm{C}$ was not significant for the responses. Furthermore, the effect of inoculum size for $L$. casei on fermentation of goat milk was studied, and optimum inoculum size of L. casei was $7 \%$, the viable counts and total bacteria were $2.8 \times 10^{8} \mathrm{cfu} / \mathrm{mL}, 2.2 \times 10^{9} \mathrm{cfu} / \mathrm{mL}$, respectively (Chen et al., 2015), which was very closed to the data as shown in Table 3.

The ANOVA summary showed in Table 4 the model for total bacteria was significant, with a p-value less than 0.05 and $\mathrm{F}$-value of 5.37. A lack-of-fit with $\mathrm{F}$-value 2.74 was not significant. It very fitted with model equation as described in Eq. (3). The coefficient of determination $\mathrm{R}^{2}$ was 0.9063 and the adjusted determination coefficient was 0.7375 , indicated that the model had a high potential for predicting the response. Parameter of $\mathrm{C}$ was the main factor affecting the total bacteria, as revealed by the respective regression. It had a significant linear effect on the total bacteria as depicted in Fig. 1c. As it shown that the two-dimensional contour plots seemed to be a circle; this indicates that the mutual interaction of terms $\mathrm{A} \times \mathrm{B}$ was not significant for the responses. Besides, the linear effects of $\mathrm{A}$ and $\mathrm{B}$ on total bacteria were not significant too as shown in Table 4. Pairwise interactions between the parameters of $\mathrm{A}, \mathrm{B}$ and $\mathrm{C}$ were very weak.

The high F-value (9.52) for sensory evaluation indicated the model was significant. A lack-of-fit with F-value (2.45) was not significant. Model equation as described in Eq. (4) was confirmed to be a suitable model. The coefficient of determination $\mathrm{R}^{2}$ was 0.9449 , showed that more than $94.49 \%$ of variability in the response could be explained by predicted equation given in already. Parameter of A was the main factor affecting the sensory value and it was very significant. Furthermore, the quadratic $\left(\mathrm{A}^{2}\right)$ and interaction terms $(A \times C)$ were significant too. The interaction of fermentation temperature and inoculum size was depicted in Fig. 1d. When the fermentation temperature is at a low level, increasing the inoculum size gave an increase in sensory score; while it is at a high level, the change trend is just the opposite. When the inoculation is at a low level, sensory scores increased with increasing fermentation temperature; while it is at a high level, sensory scores increased first and then decreased following increase of fermentation temperature.

According to Box-Behnken experimental results and quadratic regression equation, the optimum fermentation conditions which were calculated by statistical software Design-Expert 7.1.6 were: Fermentation temperature, $41^{\circ} \mathrm{C}$; the strain ratio, $2: 1: 1$; inoculum size, $6 \%$. Validate experimental was down based on optimum conditions which is given by Design-export. The viable counts of B.bifidum, L. casei, total bacteria and sensory value reached at $(1.31 \pm 0.07) \times 10^{8} \mathrm{cfu} / \mathrm{mL},(2.67 \pm 0.09) \times 10^{7} \mathrm{cfu} / \mathrm{mL}$, $(1.62 \pm 0.06) \times 10^{9} \mathrm{cfu} / \mathrm{mL}$ and $7.52 \pm 0.11$, respectively. Which is very close to the predicted values of the 
corresponding response value that given by Box-Behnken design.

\section{CONCLUSION}

The health beneficial effects of yogurt are may related to the high viable counts of probiotics in the product when consumption.In the present study, the optimum fermentation temperature, strain ratio (BB: LC:(LB: ST)) and inoculum size in the goat yogurt was $41^{\circ} \mathrm{C}, 2: 1: 1$ and $6 \%$, respectively. The viable counts of $B$. bifidum, $L$. case $i$, total bacteria and sensory value reached at $(1.31 \pm 0.07) \times 10^{8} \mathrm{cfu} / \mathrm{mL},(2.67 \pm 0.09) \times 10^{7} \mathrm{cfu} / \mathrm{mL}$, $(1.62 \pm 0.06) \times 10^{9} \mathrm{cfu} / \mathrm{mL}$ and $7.52 \pm 0.11$, respectively. There was no significant difference between predicted value and the verification results $(p<0.05)$. Results between the predicted value and actual value indicated the established model in this study is feasible and effective. The optimized method can be used to further investigate the function products of goat milk and the role of processing and storage.

\section{ACKNOWLEDGEMENT}

The work was partly supported by the Science and Technology Overall Planning for innovation Engineering project of Shaanxi Province, China (No. 2016KTZDNY02-03) and the Scientific Research Program Funded by Shaanxi Provincial Education Department (No.15JF008).

\section{Author contributions}

C. B. wrote the article and corrected it. H. C. and G. S. designed the study. C. B. and C. W. conducted the experimental work.

\section{REFERENCES}

Albenzio, M. and A. Santillo. 2011. Biochemical characteristics of ewe and goat milk: Effect on the quality of dairy products. Small Ruminant Res. 101: 33-40.

Ara, K. M., Z. Akhoondpouramiri and F. Raofie. 2013. Carrier mediated transport solvent bar microextraction for preconcentration and determination of dexamethasone sodium phosphate in biological fluids and bovine milk samples using response surface methodology. J. Chromatogr. B. 931: 148-156.

Box, G. E. P. and E. W. Behnkin. 1960. Some new 3 level designs for the study of quantitative variables. Technolnetrics. 2: 455-475.

Betoret, N., L. Puente, M. J. Diaz, M. J. Pagan, M. J. Garcia and M. L. Gras. 2003. Development of robiotic-enriched dried fruits by vacuum impregnation. Food Eng. 56: 273-277.

Burgain, A., M. Bensoussan and P. Dantigny. 2013. Effect of inoculum size and water activity on the time to visible growth of Penicillium chrysogenum colony. Int. J. Food Microbiol. 163:180-183.

Collado, M. C., J. Meriluoto and S. Salminen. 2007. Development of new probiotics by strain combinations: Is it possible to improve the adhesion to intestinal mucus? J. Dairy Sci. 90: 2710-2716.

Chen, H., C. F. Wang, G. W. Shu, D. Peng and J. J. Zhang. 2010. Technological optimization of setstyle goat yogurt fermentation. Food Sci. Technol. 35: 71-74.

Chen, H., Q. Zhang, H. C. Wan, G. W. Shu and H. Li. 2015. Effect of Total Inoculum Size Containing Lactobacillus acidophilus or Lactobacillus casei on Fermentation of Goat Milk. Adv. J. Food Sci. Technol. 7: 183-186.

Desrouillères, K., M. Milletteb, K. D. Vua, R. Toujaa and M. Lacroix. 2015. Cancer preventive effects of a specific probiotic fermented milk containing Lactobacillus acidophilus CL1285, L.casei LBC80R and L. rhamnosus CLR2 on male F344 rats treated with 1,2-dimethylhydrazine. J. Funct. Foods. 17: 816-827.

Gao, S. B. 2004. The latest progress of fermented milk. J. China. Dairy Ind. 32: 46-49.

Guler-Akın, M. B. and M. S. Akın. 2007. Effects of cysteine and different incubation temperatures on the microflora, chemical composition and sensory characteristics of bio-yogurt made from goat's milk. Food Chem. 100: 788-793.

Haenlein, G. F. W. 2004. Goat milk in human nutrition. Small Ruminant Res. 51: 155-163.

Haenlein, G. F. W. and M. Anke. 2011. Mineral and trace element research in goats: A review. Small Ruminant Res. 9: 95: 2-19.

Keogh, M. K. and B. T. O'Kennedy. 1998. Rheology of stirred yogurt as affected by added milk fat, protein and hydrocolloids. J. Food Sci. 63: 108-112.

Kanmani, P., R. Satish Kumar, N. Yuvaraj, K. A. Paari, V. Pattukumar and V. Arul. 2013. Probiotics and its functionally valuable products-a review. Crit. Rev. Food Sci. Nutr. 53: 641-658.

Marco, M. L., S. Pavan and M. Kleerebezem. 2006. Towards understanding molecular modes of probiotic action. Cur. Opin. Biotechnol. 17: 204-210.

Ming, L. C., A. A. Rahim, H. Y. Wan, B. Arbakariya and A. B. Ariff. 2009. Formulation of Protective Agents for Improvement of Lactobacillus salivarius I 24 survival rate subjected to freeze drying for production of live cells in powderized form. Food Bioprocess Technol. 2: 431-436.

Minervini, F., M. T. Bilancia, S. Siragusa, M. Gobbetti and F. Caponio. 2009. Fermented goats' milk produced with selected multiple starters as a potentially functional food. Food Microbiol. 26: 559-564.

Million, M. and D. Raoult. 2012. Publication biases in probiotics. Eur. J. Epidemiol. 27: 885-886.

Pinho, C., A. Melo, C. Mansilha and I. M. Ferreira. 2011. Optimization of conditions for anthocyanin hydrolysis from red wine using response surface methodology (RSM). J. Agric. Food Chem. 59: 50-55.

Radke-Mitchell, L. and W. E. Sandine. 1986. Influence of temperature on association growth of Streptococcus thermophilus and Lactobacillus bulgaricus: A review. J. Dairy Sci. 69: 2558-2568.

Rafter, J. 2003. Probiotics and colon cancer. Best Pract. Res. Clin. Gastroenterol. 17: 849-859.

Raynal-Ljutovac, K., P. Gaborit and A. Lauret. 2005. The relationship between quality criteria of goat milk, its technological properties and the quality of the final products. Small Rumin. Res. 60: 167-177.

Saarela, M., L. Lähteenäki, R. Crittenden, S. Salminen and T. MattilaSandholm. 2002. Gut bacteria and health foods-the European perspective. Int. J. Food Microbiol. 78: 99-117.

Siti Aminah, S., A. H. Aidil and W. Y. Wan Mohtar. 2006. Medium 
optimization for the production of lipidless biomass by Cunninghamella sp. 2A1 Using response surface methodology. Malays. J. Microbiol. 2: 40-45.

Sheehan, J. J., A. D. Patel, M. A. Drake and P. L. H. Mcsweenwy. 2009. Effect of partial or total substitution of bovine for caprine milk on the compositional, volatile, nonvolatile and sensory characteristics of semi-hard cheeses. Int. Dairy J. 19: 498-509.

Silanokove, N., G. Leitner, U. Merin and C. G. Prosser. 2010. Recent advances in exploiting goat's milk: Quality, safety and production aspects. Small Rumin. Res. 89: 110-124.

Shu, G. W., Z. X. Ma, Z. W. Wang and H. Chen. 2011. Effect of bile and nalidixic acid on growth of selected probiotics. Adv. Mater. Res. 322: 248-251.

Shu, G. W., S. Wang, Z. K. Chen, H. Chen, C. F. Wang and Y. N. Ma. 2015a. Effect of bacteria proportion on the fermentation of goat yoghurt with probiotic culture. Acta Sci. Pol. Technol. Aliment. 14: 407-414.

Shu, G. W., S. N. Lei, H. C. Wan, H. Chen and H. Li. 2015b. Effect of bacteria proportion on the fermentation of goat yoghurt with probiotic culture. Carpathian J. Food Sci. Technol. 7: 28-35.

Scholz-Ahrensa, K. E., B. Adolphia, F. Rochatb, D. V. Barclay, M. D.
Vresea, Y. Acil and J. Schrezenmeira. 2016. Effects of probiotics, prebiotics, and synbiotics on mineral metabolism in ovariectomized rats - Impact of bacterial mass, intestinal absorptive area and reduction of bone turn-over. N. F. S. J. 3: 41-50.

Torriani, S., F. Gardini, M. E. Guerzoni and F. Dellaglio. 1996. Use of the response surface methodology to evaluate some variables affecting the growth and acidification characteristics of yogurt cultures. Int. Dairy J. 6: 625-636.

Tharmaraj, N. and N. P. Shah. 2000. Probiotic bacteria: Selective enumeration and survival in dairy foods. J. Dairy Sci. 83: 894-907.

Unno, T., J. H. Choi, H. G. Hur, M. J. Sadowsky, Y. T. Ahn, C. S. Huh, G. B. Kim and C. J. Cha. 2015. Changes in human gut microbiota influenced by probiotic fermented milk ingestion. J. Dairy Sci. 98: 3568-3576.

Van de Guchtel, M., S. Penaud, C. Grimaldi, V. Barbe, K. Bryson and P. Nicolas. 2006. The complete genome sequence of Lactobacillus bulgaricus reveals extensive and on going reductive evolution. Proc. Natl. Acad. Sci. USA. 103: 9274-9279.

Wang, L., L. Y. Zheng and S. M. Zhou. 2002. Development of sour ewe's milk. Guangzhou Food Sci. Technol. 18: 17-19. 